\title{
EGY THORNTHWAITE TÍPUSÚ VÍZMÉRLEG MODELL AZ ÉGHAJLATVÁLTOZÁS HIDROLÓGIAI HATÁSAINAK ELEMZÉSÉHEZ
}

\author{
Herceg András ${ }^{1}$, Kalicz Péter ${ }^{1}$, Kisfaludi Balázs ${ }^{1}$ és Gribovszki Zoltán ${ }^{1}$ \\ ${ }^{1}$ Soproni Egyetem, Geomatikai, Erdőfeltárási és Vizgazdálkodási Intézet
}

\begin{abstract}
Kivonat
A globális átlaghőmérséklet emelkedése drasztikus hatással lehet a vízkörforgalomra. Jelen tanulmány célja egy Thornthwaite típusú havi vízmérlegmodell kifejlesztése, kalibrálása távérzékelt evapotranszspirációs adatbázis felhasználásával. A kalibrált modellt 4 regionális klímamodell segítségével az aktuális párolgás és a talajnedvesség elörevetítésre is használtuk, a 2010-2040, 2040-2070, és 2070-2100-as periódusokra, feltételezve az IPCC SRES A1B kibocsátási forgatókönyvet, összevetve az 1980/2010-es referenciai-időszakkal. A modell elönye, hogy kizárólag havi hömérséklet és csapadék idősorokat igényel bemeneti paraméterként (robosztus felépités). A kalibrációs paraméter a talaj víztározó kapacitása (SOIL $\mathrm{MAX}$ ), amelyet az elérhető aktuális párolgás adatbázissal kalibráltunk. Ha a talajizikai paraméterek ismertek, a maximális gyökérmélység is meghatározható. A modell vízgyüjtőszinten, vagy olyan területeken alkalmazható, ahol nincs járulékos vízutánpótlás a felszínről vagy felszín alól. A modell tesztelésére egy Mosonmagyaróvár melletti vegyes felszínborítású parcellát és egy Sopron melletti erdős kisvízgyüjtőtt választottunk. Szárazságstresszre vonatkozó paramétereket is meghatároztunk a relativ hasznositható víz (REW) és a talajvíz deficit (SWD) révén. A modellt sikeresen kalibráltuk egy vegyes felszínboritású parcellára és egy erdő borította vízgyüjtöre észak-nyugat Magyarországon.
\end{abstract}

Kulcsszavak: havi vízmérleg, klímaváltozás, evapotranszspiráció, talajnedvesség, szárazságstressz.

\section{A THORNTHWAITE-TYPE WATER BALANCE MODEL FOR THE ANALYSIS OF THE HYDROLOGICAL IMPACT OF CLIMATE CHANGE}

\begin{abstract}
The global temperature increase is expected to cause severe impacts on the water balance. The objective of this paper was to develop a new monthly step model based on a Thornthwaite-type monthly water balance estimation and calibrate the model parameters using remote sensing-based evapotranspiration dataset. The calibrated model was also used for projection based on the simulation results of 4 regional climate models applying the IPCC SRES A1B emission scenario. The 3 periods of projection were: 2010-2040, 2040-2070, and 2070-2100 compared to the reference period (1980/2010). The benefit of our method is its robust structure; therefore it can be applied if temperature and precipitation time series are accessible. The key parameter is the water storage capacity of the soil (SOIL ${ }_{\mathrm{MAX}}$ ), which can be calibrated using the actual available evapotranspiration data as well. If the soil's physical properties are available, the maximal rooting depth is also projectable. The model can be used at the catchment level or for areas without additional water amounts from below. We have determined parameters (REW; SWD) to evaluate the water stress during the $21^{\text {st }}$ century. The model has been successfully calibrated for a mixed parcel and for a small forest covered catchment in Northwest Hungary.
\end{abstract}

Keywords: water balance, climate change, evapotranspiration, soil moisture, water stress. 


\section{BEVEZETÉS}

A kontinensekre hulló csapadék 62\%-a elpárolog (Dingman 2002), tehát a párolgás modellezésének (számszerüsítésének) fontossága globális szinten vitathatatlan. Kifejezetten igaz ez a klímaváltozással kapcsolatos előrejelzések szemszögéből hazánkban, ahol a lehullott csapadék 90\%-a elpárolog (Kovács 2011).

A párolgás tehát fontos a hozzáférhető vízkészletek szempontjából, s egyúttal szabályozza a növények elterjedését és az elsődleges termelést is (Neilson 1995, Vörösmarty és mtsai 1988). A világ élelmiszer-termelésének alapjául szolgáló földterületek java része öntözés alatt áll, tehát az elpárolgott öntözővízről szerzett tudás alapvető fontosságú (Dingman 2002). Ennek ellenére, még manapság is a vízmérleg legkevésbé ismert része a párolgás (Wilson és mtsai 1992).

Globális szinten, a 21. század végére azok a klíma-forgatókönyvek, melyek figyelmen kívül hagyják a folyamat enyhítésére szolgáló intézkedéseket, $3,7-4,8{ }^{\circ} \mathrm{C}$-os hömérsékletnövekedéssel számolnak az 1850-1900-as referencia időszakhoz képest (alapul az iparosodás előtti kibocsátási szinteket tekintve) (IPCC 2014).

Az Európai regionális klíma-előrejelzések tekintetében szintén általános egyetértés van, amely statisztikailag szignifikáns melegedést jelent minden évszakban (Christensen és mtsai 2007; Jacob és mtsai 2008; Linden van der és Mitchell 2009). Vautard és mtsai (2014) Európa klímájának változását kutatták a $2{ }^{\circ} \mathrm{C}$-os globális felmelegedéshez kapcsolódóan (amely az iparosodás előtti időszakokhoz képest értelmezendő). A globális klíma szimulációk (SRES A1B forgatókönyvek alapján, 30 éves vizsgálati periódus) eredményeit skálázták le 25 kilométeres felbontásra regionális klímamodellek segítségével. A globális $2{ }^{\circ} \mathrm{C}$-os átlaghoz képest az Európai hőmérséklet-növekedés feltételezhetően magasabb lesz (referenciaként az 1971-2000-es időszakot vették.

Magyarországon a felmelegedés az elmúlt 30 évben vált a legintenzívebbé. Legfőképpen a nyári hőmérsékletek emelkedtek, közel $2^{\circ} \mathrm{C}$-kal (Bartholy és mtsai 2011, HREX 2012). A 21. századra készített klíma elörejelzések közös álláspontot képviselnek a hazai emelkedö hőmérsékletek (minden évszakban) és a fokozódó klimatikus ariditás tekintetében (Gálos, 2015). Az elörevetített melegedés $2-5^{\circ} \mathrm{C}$ között várható az alkalmazott klímamodell és kibocsátási forgatókönyv függvényében (Nováky és Bálint 2013; Pongrácz és mtsai 2011). A legszélsőségesebb esetben a 21. század végére, a hazai éves átlaghőmérséklet megegyezhet a déli mediterrán területek jelen átlagaival (Mika 1999; URL1).

A klímaváltozás a hőmérséklet-emelkedésen túl - a változó csapadékmintázaton és párolgáson keresztül - jelentősen befolyásolhatja a vízkörforgalmat, hiszen a magasabb hömérséklet magasabb energiapotenciált reflektál az atmoszférába, amely gyorsítja a hidrológiai ciklust (Sun és mtsai 2008; Szilágyi és Józsa 2008). Ez a gyorsulás pedig változásokat eredményez a csapadék időbeli eloszlásában, amely az egy csapadékesemény alatti menynyiségnövekedést idézi elő, miközben az éves csapadékmennyiség nem mutat jelentős változást. 
Granier és mtsai (1999); Lutz és mtsai (2010); Remrová és Císleřová (2010); Keables és Mehta (2010) vízmérlegmodellek hatás elemzésével foglalkoztak.

Granier és mtsai (1999) napi léptékű vízmérlegmodellt készített erdőállományok vízmérlegének meghatározására, azzal a céllal, hogy számszerüsítse a szárazság intenzitását és időtartamát Franciaország különböző régióiban. Ez a modell szintén robosztus, mivel bementi paraméterként potenciális párolgást (Penman-Monteith), csapadékot, és levélfelületi indexet használ. A modellben a maximális hasznositható vízkészlet nem kalibrációs modell paraméter, hanem az adott helyre becsült érték. A modell az állományi transzspirációt, intercepciót és talajnedvesség-tartalmat számol. Granier és mtsai (1999) a talajprofilt néhány horizontális rétegre osztva vették figyelembe. Kalibrációként transzspirációs nedváramlásmérést végeztek. A validáció a mért, és az egyhetes frekvenciájú szimulált talajnedvesség összevetésével történt.

Remrová és Císleřová (2010) egy füborítású kísérleti vízgyüijő (Uhliřska, Csehország) vízmérlegét vizsgálta. Előrejelzéseket végeztek a 2071-2100-as vizsgálati periódusra, egyetlen regionális klímamodell (HIRHAM/HadCM3, SREC A2 forgatókönyv) eredményeit felhasználva. Vizsgálták a szárazságstresszt is, amely kutatásaikban a kalkulált potenciális párolgás és a szimulált párolgás különbségéből adódik.

Lutz és mtsai (2010) a Yosimite Nemzeti Park (USA) legelterjedtebb fafajainak eloszlását elemezte a vízmérleg változók (az éves vízmérleg deficit (PET-AET) és az aktuális párolgás AET) összefüggésében, a kitettséget, a lejtést és a talaj víztározó kapacitását is figyelembe véve. Egy módosított, havi időlépcsős Thornthwaite típusú vízmérlegmodellt használt, Hamon PET megközelítéssel (Dingman 2002). Klíma-elörejelzéseket alapul véve aktuális párolgást és deficitet (PET-AET) számoltak a múlt és jövő klímájára (Lutz és mtsai 2010).

Keables és Mehta (2010) a talajban rendelkezésre álló vízkészletek klimatikus függését elemezték, a jellemző talajtípusokhoz kapcsolódóan Kansas tagállam (USA) területén, egy havi időlépcsős Thornthwaite vízmérlegmodellt felhasználva. Bemeneti paraméterek a hömérséklet és csapadék, mellyel a Hamon-féle PET került meghatározásra az 1950-2006-os időszakra. Emellett aktuális párolgást, talajviz-felhasználást, utánpótlódást és lefolyást is meghatároztak. Elörejelzéseket azonban nem végeztek a vízmérleg paramétereire.

A bemutatott tanulmányok tekintetében elmondható, hogy kevés foglalkozik a vízmérleg tételeinek kiértékelésével, és jövőbeli alakulásával úgy, hogy kevés bemeneti paraméterigényü modellt alkalmaz, és ezáltal könnyen kiterjeszthető is. Mindazonáltal csak néhány tanulmány célozta meg a klímaváltozás vízmérlegre gyakorolt hatásainak felfedését a 21. századra, amely a Kárpát-medence speciális éghajlati sajátosságait is figyelembe veszi.

A jelen kutatás fő célja egy havi időlépcsős vízmérlegmodell kifejlesztése. A fejlesztett modell egy meglévő robosztus havi vízmérleg modell egyenleteit veszi alapul, azonban aktuális párolgást is használó kalibrációs eljárással lett továbbfejlesztetve, és regionális célokra alkalmazható. A kifejlesztett modell segítségével pedig a mezőgazdasági és az erdészeti szektorra (olyan területekre, amelyek nem rendelkeznek járulékos felszíni vagy felszín alatti vízutánpótlódással) gyakorolt éghajlat-változási hatások feltárása, számszerüsítése. 


\section{ADAT ÉS MÓDSZER}

\section{Kutatási terület}

A modellünk tesztelésére két kutatási területet jelöltünk ki, amelyek Magyarországon, a Nyugat-Dunántúlon találhatóak (1. ábra).

Az erdős terület egy $6 \mathrm{~km}^{2}$ összterületü kísérleti vízgyüjtő az Alpok keleti lábánál, nem messze Soprontól. A terület éghajlata szubalpin. Az átlagos évi középhőmérséklet $8,5^{\circ} \mathrm{C}$. Az éves csapadékösszeg 700-750 mm. A legszárazabb évszak az ősz, a legnedvesebb pedig a nyár és a késő tavasz (Danszky 1963, Marosi-Somogyi 1990). A vízgyüjtő geológiai alapja folyami üledék, amely a kristályos kőzeten öt rétegben rakódott le a harmadidőszakban (Miocén). A finomabb szemcséjü réteg a völgytalpban jelenik meg, amely egyúttal jó víztartó (Kisházi-lvancsics 1985). A fizikai talajféleség agyag. Az uralkodó fafajok a vízgyüjtőn a lucfenyő (Picea Abies) és a bükk (Fagus sylvatica) az északi lejtökön, valamint kocsánytalan tölgy (Quercus petraea) és bükk a déli lejtökön.

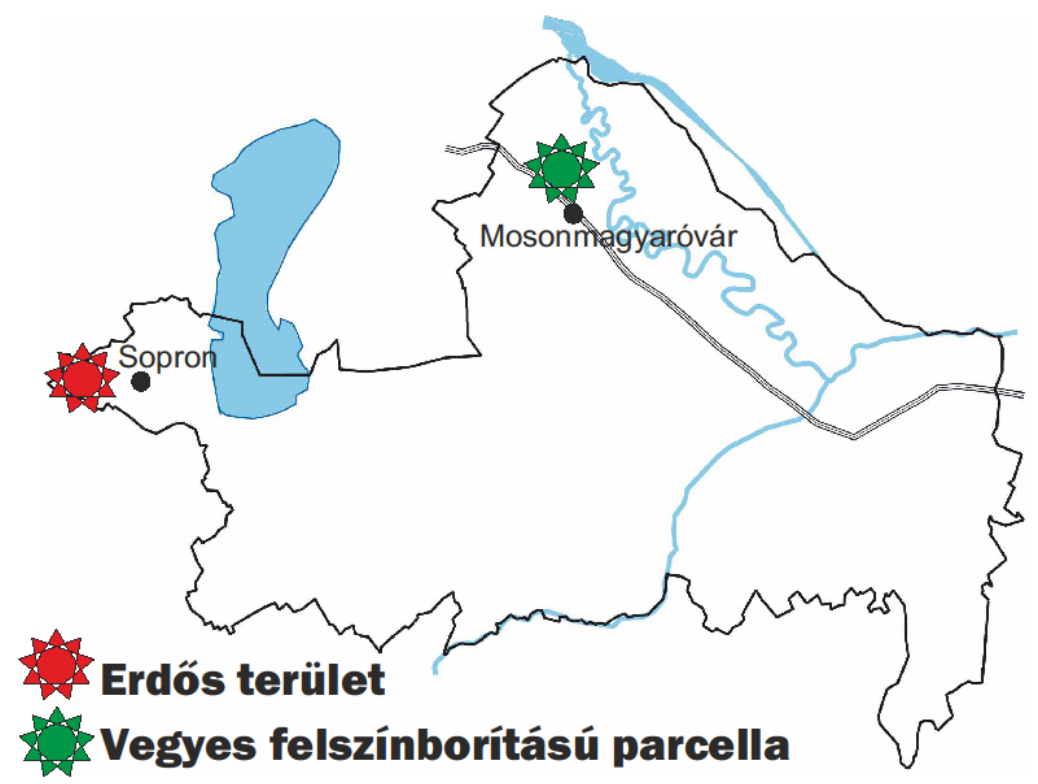

1. ábra: A kutatási területek. A koordinátáik a következők: $47^{\circ} 40^{\prime} 11.3^{\prime \prime} \mathrm{N} ; 16^{\circ} 27^{\prime 3} 31.1^{\prime \prime} \mathrm{E}$ (erdős terület) és $47^{\circ} 54^{\prime} 19,20^{\prime \prime} \mathrm{N} ; 17^{\circ} 15^{\prime} 09,89^{\prime \prime} \mathrm{E}$ (vegyes felszínboritású parcella).

Figure 1: The study areas. The coordinates of the them are the following: $47^{\circ} 40^{\prime} 11.3^{\prime \prime} \mathrm{N}$; $16^{\circ} 27^{\prime} 31.1^{\prime \prime} \mathrm{E}$ (forested area) and $47^{\circ} 54^{\prime} 19,20^{\prime \prime} \mathrm{N} ; 17^{\circ} 15^{\prime} 09,89^{\prime \prime} \mathrm{E}$ (mixed parcel). 
A második kutatási terület az úgynevezett 'vegyes felszínborítású parcella', amely alapvetően egy mezőgazdasági terület, jellemzően kukoricaföld. 2003 és 2007 kivételt képez, hiszen ebben a két évben árpát, 2004-ben pedig búzát termesztettek. A parcella teljes területe $1 \mathrm{~km}^{2}$, amelyen nemesnyár-fasorok (Populus $\times$ Canadensis) is találhatók (arányaiban ez 10\%-os jelent). A terület a Mosoni-sík kistájon található, Győr-Moson-Sopron megyében. Geológiai értelemben a Duna hordalékkúp déli felhalmozódásos lejtője, amely a süllyedő mélyedése a Kisalföldnek. A kistáj észak-nyugati részén folyami hordalék és folyami kavics borítja a felszínt a Lajta két oldalán, de a déli és délkeleti részen üledékes iszapos-lösz borította felszín található. Az éghajlat kontinentális. A kistáj nyugati felén (ahol a parcella található) $9,7^{\circ} \mathrm{C}$ az átlagos évi középhömérséklet. Az éves csapadékösszeg $560 \mathrm{~mm}$. Kavicson fejlődött hidromorf talaj jellemzi a kistájat. Továbbá a nyárfa ültetvények aránya jelentős a kistájon (Dövényi 2010).

\section{Alkalmazott adatbázisok}

A modell kalibrálásához havi aktuális párolgás térképeket használtunk fel (ET CREMAP).

Bouchet (1963) komplementáris elméletén alapulva Morton és mtsai (1985) megalkották WREVAP modelljét regionálisan reprezentatív, aktuális evapotranszspiráció értékek számítására. Szilágyi és Józsa (2009), Szilágyi és mtsai (2011) kifejlesztettek egy metódust (CREMAP), amellyel a komplementáris elmélet alapján számított pontszerü aktuális evapotranszspiráció adatok és távérzékelt felszíni hőmérséklet térképek segítségével, a térben változó aktuális párolgás havi szinten számíthatóvá válik. A módszer alapja egy lineáris transzformáció. Ez a transzformáció 8 napos összetett MODIS nappali felszíni hőmérséklet adatokat konvertál aktuális párolgás értékekre (Szilágyi és Józsa 2009). Kovács (2011) az előbbi modellt felhasználva havi aktuális párolgás térképeket készített (ETCREMAP) Magyarországra, a 2000 és 2008 közötti periódusra, március és november hónapok közötti időszakokra.

\section{Thornthwaite típusú hidrológiai modell leírása}

Az Agrárklíma.2 projekt hőmérséklet ( $\left.\mathrm{T}_{\mathrm{M}}\right)$ és csapadék ( $\left.\mathrm{P}_{\mathrm{M}}\right)$ adatbázisa, valamint a távérzékelt aktuális párolgás térképek adatsora (ETCREMAP) (Szilágyi és mtsai 2010, Kovács 2011) szolgáltak a modell bemeneti adataiként.

Az alap vízmérleg modell C.W. Thornthwaite nevéhez füződik (Thornthwaite 1955), amelyet továbbfejlesztve és azt a kutatás céljához hozzáigazítva hoztuk létre saját új és regionálisan alkalmazható modellünket.

A Thornthwaite típusú vízmérlegmodellt a hidrológusok szezonális szimulációkhoz, elsősorban a hó felhalmozódás, a talajnedvesség és a párolgás tanulmányozására használják. 
A bemeneti adatokat a havi csapadékösszegek és átlaghőmérsékletek képezik (Dingman 2002).

Az eredeti Thornthwaite-modell módosított változatának (Dingman 2002) kalibrálása aktuális párolgás adatok felhasználásával történt (Kovács 2011).

Az aktuális párolgás a felszínről párolgó és a növények párologtatása során keletkező vízmennyiségből tevődik össze, ha a rendelkezésre álló vízkészlet korlátozott.

A saját fejlesztésű vízmérlegmodell kalibrációjának időintervalluma a párolgástérképek rendelkezésre állásának időszaka volt (2000-2008).

A modellállítás első lépése a potenciális párolgás (PET [mm · nap-1]) meghatározása.

A potenciális párolgáson azt az értéket értjük, ami egy nagy, növényzettel egyenletesen és teljesen borított területen jelenne meg, amennyiben a fejlődő növényzet korlátlan vízkészletekhez férne hozzá, advekció és a hőtárolás hatásai nélkül (Dingman, 2002).

Hamon (1963) nyomán mi egy hőmérséklet alapú, globálisan kalibrált PET modellt használtunk $(\mathrm{PETH})$.

$$
\begin{aligned}
& e_{m}{ }^{*}=0,611 \cdot \exp \left(\frac{17,3 \cdot T_{m}}{T_{m}+237,3}\right) \\
& \text { PET }_{H}=29,8 \cdot D \frac{e_{m}^{*}}{T_{m}+273,2}
\end{aligned}
$$

Ahol:

D: naphossz [óra]

$\mathrm{T}_{\mathrm{a}}$ : átlagos havi hőmérséklet $\left[{ }^{\circ} \mathrm{C}\right]$

$\mathrm{e}_{\mathrm{a}}{ }^{*}$ : telítési páranyomás $[\mathrm{kPa}]$.

A havi időlépcső miatt a PETH értékét [mm· hónap $\left.{ }^{-1}\right]$ mértékegységre kellett átváltani.

A következő lépés egy feltétel volt.

$\mathrm{Ha}$ :

$\mathrm{P}_{\mathrm{M}} \geq \mathrm{PET}_{\mathrm{M}}$

Akkor:

$\mathrm{ET}_{\mathrm{M}}=\mathrm{PET}_{\mathrm{M}}$

$\mathrm{SOIL}_{M}=\min \left\{\left[\left(\mathrm{P}_{\mathrm{M}^{-}} E \mathrm{~T}_{M}\right)+\mathrm{SOIL}_{\mathrm{M}-1}\right], \mathrm{SOIL}_{\mathrm{MAX}}\right\}$

Ahol:

SOILmAX: a talaj víztároló képessége [mm]

$\mathrm{PET}_{\mathrm{M}}$ kalibrált havi potenciális párolgás [mm].

A PETM meghatározása a kalibráció része, ami a következő alfejezetben kerül bemutatásra. 
A modellben szereplő talajnedvesség nem a talajban tárolt teljes mennyiségét jelenti, hanem a növényzet számára elérhető teljes vízmennyiséget.

A kezdő SOIL M- $_{\text {érték SOIL }}$ MAX-ra lett beállítva, mivel a modellezés nyugalmi időszakban kezdődött, így feltételezhető a talaj telítettsége. A SOILmax értékének meghatározása egy adott területre a következő:

$\operatorname{SOIL}_{\mathrm{MAX}}=\left(\theta_{\mathrm{fc}}-\theta_{\mathrm{pwp}}\right)^{*} \mathrm{Z}_{\mathrm{rz}}$

Ahol:

$\theta_{\text {fc: }}$ szántóföldi vízkapacitás [dimenzió nélküli],

$\theta_{\text {pwp: }}$ hervadásponti víztartalom [dimenzió nélküli],

Zrz: gyökérzóna vertikális kiterjedése [mm].

A SOILmAx értéke a kalibráció előtt 1 méteres szabványos kezdő termőréteg vastagságra lett beállítva.

$\mathrm{Ha}:$

$\mathrm{P}_{\mathrm{M}}<\mathrm{PET} \mathrm{T}_{\mathrm{M}}$

Akkor:

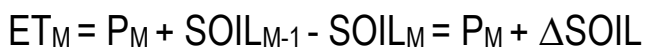

Ahol:

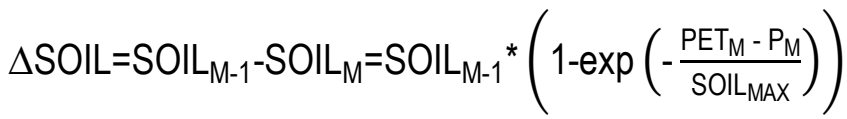

$\Delta$ SOIL: A talajnedvesség-változás értéke [mm].

\section{Modell kalibráció}

A modell kalibrációja a modellfejlesztés részét képezi. A kalibráció alapvetően két különálló részre bontható: a potenciális párolgás $\left(P E T_{H}\right)$ és az aktuális párolgás $\left(E T_{M}\right)$ kalibrálása az adott felszínborításra az aktuális párolgástérképek (ETCREMAP) felhasználásával.

A potenciális párolgás kalibrációjához a 'segmented' nevü ' $R$ ' programcsomagot használtunk. Az 'R' egy szabad szoftver környezet, amely elsősorban statisztikai számításokhoz és grafikához használható (R Core Team 2012).

\section{Elörevetítés}

Az előrevetítés 4 regionális klímamodell (RCM) segítségével történt, melyek fő paraméterei a 1. táblázatban találhatóak. 
1. táblázat: Az alkalmazott regionális klímamodellek (Lenderink és mtsai 2003; Jacob 2001; Jacob és mtsai 2007; Christensen és van Meijgaard 1992; Jones és mtsai 2004).

Table 1: The applied regional climate models (Jacob 2001; Jacob et al., 2007;

Christensen and van Meijgaard 1992; Christensen et al., 1996; Jones et al., 2004).

\begin{tabular}{|c|c|c|c|c|c|}
\hline $\begin{array}{c}\text { Modell } \\
\text { azonosító }\end{array}$ & $\begin{array}{c}\text { Kutatóinté- } \\
\text { zet }\end{array}$ & Modell & $\begin{array}{c}\text { Globális klíma- } \\
\text { modell (GCM) }\end{array}$ & $\begin{array}{c}\text { Forgató- } \\
\text { könyv }\end{array}$ & $\begin{array}{c}\text { Felbon- } \\
\text { tás }\end{array}$ \\
\hline 1 & MP_I & REMO & ECHAM5 & A1B & $25^{\star} 25 \mathrm{~km}$ \\
\hline 2 & SMHI & RCA & ECHAM5-r3 & A1B & $25^{\star} 25 \mathrm{~km}$ \\
\hline 3 & DMI & $\begin{array}{c}\text { HIR- } \\
\text { HAM5 }\end{array}$ & ECHAM5 & A1B & $25^{\star} 25 \mathrm{~km}$ \\
\hline 4 & KNMI & RACMO2 & ECHAM5-r3 & A1B & $25^{\star} 25 \mathrm{~km}$ \\
\hline
\end{tabular}

A regionális klímamodellek havi léptékü csapadék és hőmérséklet eredményeit értékeltük ki a 2010-2100-as időszakra, amelyek felhasználásával a vízmérleg elemei (párolgás, talajnedvesség) is elörevetíthetőek. A klímamodell eredményei szisztematikus hibával terheltek, viszont feltételezhetjük, hogy ez a hiba időben nem változik. Ezért a nyers, hibakorrigálatlan modelleredmények értékelésekor a múltbeli referencia időszakhoz (1980/2010) képesti változás (3. Táblázat) megfelelően alkalmazható a hatásbecsléshez.

Az elörejelzéshez a 21. századot három vizsgálati periódusra osztottuk: 2010/2040 (2010.01.01-2040.01.01); 2040/2070 (2040.01.01.-2070.01.01.); 2070/2100 (2070.01.01.2100.01.01.). Az egyes időintervallumokra alapvető leíró statisztikai számításokat végeztünk.

\section{Szárazságstressz}

A szárazság stressz meghatározásához a relatív hasznosítható víz (REW) és a talajnedvesség deficit (SWD) meghatározása szükséges a következő (10. és 11.) egyenletek segítségével (Granier és mtsai 1999).

$\mathrm{REW}=\frac{\mathrm{SOIL}_{\mathrm{M}}}{\mathrm{SOIL}_{\mathrm{MAX}}}$

Ahol:

REW relatív hasznositható víz [dimenzió nélküli], 
Ha a $(\mathrm{R})$ EW értéke az SOIL $\operatorname{MAX}$ 40\%-a alá esik, akkor a transzspiráció folyamatosan csökken (a sztómák bezáródása miatt), és szárazságstressz jelenik meg.

$S W D=S O I L_{M A X} \cdot 0,4-S O I L_{M}$

Ha: SOILM $<0,4$ * SOILmax és ezért az SWD értékei pozitívak, szárazságstressz feltételezhetö.

Ahol:

SWD: talajnedvesség deficit [mm]

\section{EREDMÉNYEK ÉS MEGVITATÁSUK}

\section{Módszertani eredmények}

A potenciális párolgás $\left(P E T_{H}\right)$ adott felszínborításra történő kalibrálása során a jó vízellátottságot a következőképpen határoztuk meg: a csapadékmennyiség értékei $\left(\mathrm{P}_{\mathrm{M}}\right)$ meghaladják a potenciális párolgás értékeit $\left(P E T_{H}\right)$, vagy az aktuális párolgás értékei (ETCREMAP) meghaladják a potenciális párolgás értékeit.

$\mathrm{P}_{\mathrm{M}}>\mathrm{PET}_{\mathrm{H}}$ vagy $\mathrm{ET}_{\text {CREMAP }}>\mathrm{PET}_{\mathrm{H}}$

A kiválasztott ET CREMAP és PETH értékek között szegmentált regressziót állítottunk fel. A kiválasztott ET CREMAP értékeket PETCREMAP-nak fogjuk hívni.

A kiválasztott hónapokban a függő változó az adott felszínborításra vonatkozó potenciális párolgás (PETCREMAP) a független pedig a Hamon-féle potenciális párolgás $(\mathrm{PETH})$ volt. A nyugalmi időszakban és a vegetációs időszakban a potenciális párolgás értékei eltérőek a vegetáció eltérő állapota miatt. Ezért a kiválasztott PET CREMAP és a hozzá tartozó PETH adatpárok között külön-külön hoztunk létre úgynevezett szegmentált regressziós kapcsolatot a vegetációs és a nyugalmi időszakra.

A szegmentált regresszió általánosan értelmezve kettő vagy több egyenes vonallal ábrázolt lineáris kapcsolatot jelent, amelyek ismeretlen értékeknél kapcsolódnak össze. Ezeket az ismeretlen értékeket nevezik töréspontoknak (Vito 2008).

A 2. ábrán az alkalmazott szegmentált regresszió, míg az 2. táblázatban annak eredményei találhatóak. 

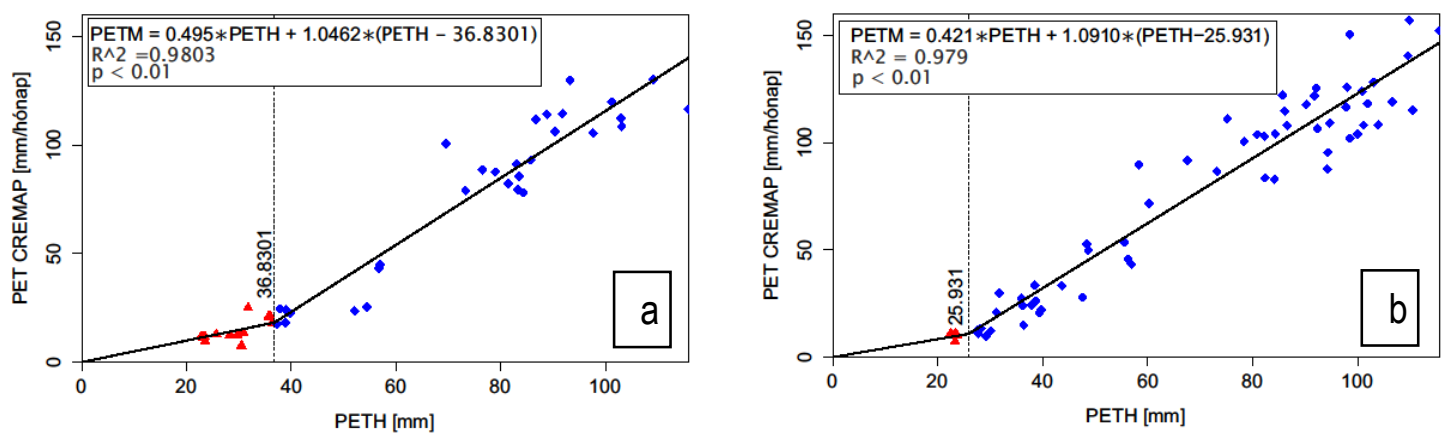

2. ábra: Regressziós kapcsolat: PETCREMAP és PETH között nyugalmi és vegetációs időszakban, a vegyes felszínborítású parcellára (a) és az erdős területre (b) nézve.

Figure 2: Relationship between ET CREMAP and PETH in growing and dormant seasons for the mixed parcel (a) and forested area (b).

2. táblázat: Szegmentált regresszió eredményei a vegyes felszínboritású parcellára és az erdős területre.

Table 2: Results of the broken line regression for the mixed parcel and the forested area.

\begin{tabular}{|c|c|c|c|c|c|}
\hline $\begin{array}{c}\text { Kutatási } \\
\text { terület }\end{array}$ & Szegmensek & Becslés* & $\begin{array}{c}\text { Standard } \\
\text { hiba** }^{* *}\end{array}$ & érték & $\operatorname{Pr}(>|t|)^{* * *}$ \\
\hline $\begin{array}{c}\text { Vegyes } \\
\text { felszínborítású } \\
\text { parcella }\end{array}$ & $\begin{array}{c}\text { 1. szegmentált } \\
\text { regressziós szakasz }\end{array}$ & 0,495 & 0,0961 & 5,145 & $<0,01$ \\
\cline { 2 - 6 } & $\begin{array}{c}\text { 2. szegmentált } \\
\text { regressziós szakasz }\end{array}$ & 1,0462 & 0,128 & 8,153 & $\mathrm{NA}$ \\
\hline \multirow{2}{*}{$\begin{array}{c}\text { Erdös } \\
\text { terület }\end{array}$} & $\begin{array}{c}\text { 1. szegmentált } \\
\text { regressziós szakasz }\end{array}$ & 0,421 & 0,284 & 1,477 & $<0,01$ \\
\cline { 2 - 6 } & $\begin{array}{c}\text { 2. szegmentált } \\
\text { regressziós szakasz }\end{array}$ & 1,0910 & 0,291 & 3,760 & $\mathrm{NA}$ \\
\hline
\end{tabular}

Az 2. táblázatban szereplő 'NA' (nem elérhető) oka, hogy a 'Pr (>|t|) értéke esetén a normál aszimptotikák nem alkalmazhatók.

*: A regressziós egyenesek iránytangensei.

**: Az iránytangensek standard hibái (mozgó szórás).

${ }^{* * *}: \operatorname{Pr}(>|t|):$ A meredekség hipotézis-tesztjének $p$-értéke. Mindkét esetben szignifikánsan különbözik nullától. A nullhipotézis szerint a meredekség értéke 0 . Mivel a p érték az esetünkben nagyon kicsi, ezért elvetjük a nullhipotézist.

Az 2. ábrán található egyenletek segítségével létre tudtuk hozni a kalibrált potenciális párolgás értékeket (PETM $[\mathrm{mm}])$.

A következő lépés az aktuális párolgás $\left(E T_{M}[\mathrm{~mm}]\right)$ kalibrációja volt. A kalibrációs paraméter ebben az esetben a talaj víztároló képessége (SOIL MAx [mm]) (Dingman 2002). 
A SOIL MAX értékét iteráció segítségével állítottuk be. Az iterálást a maximális korreláció eléréséig végeztük az $E T_{\text {CREMAP és az }} E T_{M}$ között. Ehhez 'optim' nevü függvényt használtunk a már említett 'R' szoftver segítségével. Ez a függvény, a különbség négyzetösszeg minimumát keresi.
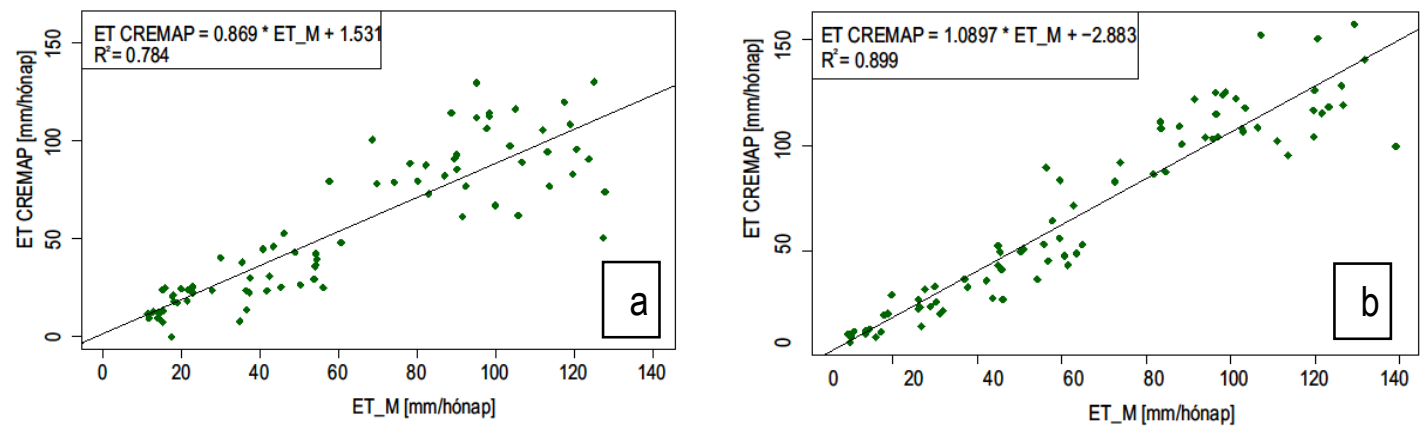

3. ábra: Regressziós kapcsolat: $E T_{M}$ és ET CREMAP között; kalibrált modell a vegyes felszínboritású parcellára (a) és az erdős területre (b) nézve.

Figure 3: Relationship between the calculated $E T_{M}$ and the measured ETCREMAP for the mixed parcel (a) and the forested area (b).

A kalibráció után az ETM és az ETCREMAP közötti kapcsolat a következő $R^{2}$ értékek segítségével jellemezhető: 0,748 (vegyes felszínborítású parcella) és 0,899 (erdős terület) (3. ábra). Az értékekből következik, hogy a modell kielégítő pontosságú. A kalibrációs fázisban az erdős területre jobb korrelációt kaptunk, amely feltehetően a homogénebb és a folyamatosan hasonló felszínboritásból adódik (közel 100\%-os erdőborítottság).

A kalibráció után, a SOILmAx értékével, valamint a talajizikai adatok segítségével, a gyökérzóna vertikális kiterjedése (és ezáltal a maximális termőréteg vastagság is) kiszámítható. A vegyes felszínborítású parcella esetén SOIL max értéke: $277 \mathrm{~mm}$, míg az erdős terület esetén $503 \mathrm{~mm}$. A gyökérzóna vertikális kiterjedése, az adott területen jellemző talaj fizikai féleség figyelembevételével, $1809 \mathrm{~mm}$ a vegyes felszínborítású parcella és $3284 \mathrm{~mm}$ az erdős terület esetén.

A nyolcéves kalibrációs időszak alatt az ETM átlagértéke $44 \mathrm{~mm} /$ hó volt a vegyes felszínborítású parcella, míg $51 \mathrm{~mm} /$ hó az erdős terület esetén. Az átlagos talajnedvesség (SOILM) értéke $197 \mathrm{~mm}$ a vegyes felszínborítású parcellán és $405 \mathrm{~mm}$ az erdős területen; míg a talajnedvesség minimumai (SOIL__MIN) a következők: 78 mm (vegyes felszínborítású parcella) és $232 \mathrm{~mm}$ (erdős terület). 


\section{Regionális klímamodellek eredményei és tendenciái}

A regionális klímamodellek 30 éves hőmérsékletátlagait tekintve elmondhatjuk, hogy 2,6 ${ }^{\circ} \mathrm{C}$-os növekedés tapasztalható a 21. század végére az 1980/2010-es referencia-időszakhoz képest. A növekedés üteme mérsékeltebb a század közepéig $\left(0,9{ }^{\circ} \mathrm{C}(2010 / 2040\right.$-es periódus)), majd fokozódik a század vége felé $\left(1,7^{\circ} \mathrm{C}(2070 / 2100)\right)$ (3. Táblázat).

A csapadék százalékos változásai szignifikáns változást nem mutatnak a 21. század folyamán, mindössze 1,81\%-os emelkedést jelent a 2070/2100-as időszakra.

3. táblázat: RCM-ek hőmérséklet átlagainak abszolút és csapadék átlagainak százalékos változásai és a szórások a vizsgált periódusokra, az 1980/2010-es referencia-időszakhoz képest.

Table 3: The RCM's mean values and standard deviations of the temperature and precipitation between 1980 and 2100.

\begin{tabular}{|c|c|c|c|c|}
\hline Paraméter & $\mathbf{1 9 8 0 / 2 0 1 0}$ & $\mathbf{2 0 1 0 / 2 0 4 0}$ & $\mathbf{2 0 4 0 / 2 0 7 0}$ & $\mathbf{2 0 7 0 / 2 1 0 0}$ \\
\hline $\mathbf{T}\left[{ }^{\circ} \mathbf{C}\right]$ & $10,7(7,1)$ & $11,6(7,5)$ & $12,4(7,4)$ & $13,3(7,5)$ \\
\hline $\mathbf{P}[\%]$ & $0(39)$ & $-1,05(42)$ & $+1,98(42)$ & $+1,81(43)$ \\
\hline
\end{tabular}

\section{A vízmérlegmodell paramétereinek eredményei és tendenciái a 21. században}

A különböző regionális klímamodell adatokkal futtatott vízmérlegmodellek közül három ('1'; '2'; '3') emelkedő tendenciát vetít elöre a 21. század végére a párolgás (ETM) tekintetében (4. ábra). Az emelkedés mértéke: $+11 \%$ mindkét kutatási terület esetén. Az ETM értékeinek, a négy klíma modell miatti szórástartománya $\sim 5 \%$-ról, 20\%-ra emelkedik. A jelentős változást a '4' modell modellátlagtól való szignifikáns eltérése okozza a 21. század végére.

A talajnedvesség (SOIL $)$ tekintetében csökkenő trend feltételezhető a 21. század végére, melynek értéke $12 \%$ a vegyes felszínboritású parcella, és $11 \%$ az erdős terület esetén (4. Táblázat).

Az 5. ábrán megjelenített talajnedvesség minimum értékek (SOIL_M_MIN) a növények számára elérhető minimumok, ezért a szárazságstressz szempontjából fontosak. A modellek átlaga szerint jelentős értékcsökkenés várható a 21. század végére, amelynek értéke: $48 \%$ a vegyes parcella és $32 \%$ az erdős terület esetén (4. Táblázat). A '4' modell jelzi elöre a legkisebb talajnedvesség minimum értékeket, mindkét felszínboritás esetén, amely $80 \%$-0s esést jelent a vegyes felszínborítású parcellán és $60 \%$-os esést az erdős területen a 2070/2100-as időszakra nézve, az 1980/2010-es referencia-időszakhoz képest (5. ábra). A '3' modell a század közepére (2040/2070) emelkedést jelez előre, mindkét vizsgált területen, ezért a SOILM_Min esetén a 2040/2070-es periódusban tapasztalható a legnagyobb modellszórás ( 100\% (vegyes felszínborítású parcella); 75\% (erdős terület)). A minimum értékek szeptember és október hónapokban jelentkeznek. 
4. táblázat: $E T_{M}$; SOIL $L_{M}$ és SOIL $L_{M}$ MIN várható változása a 4 modell átlagára és szórás a kutatási területeken az 1980/2010-es referencia időszakhoz képest.

Table 4: Rates of $E T_{M} S_{S O I L_{M}}$ and SOIL M_MIN $_{\text {with }}$ standard deviations for the study sites.

\begin{tabular}{|l|c|c|c|}
\hline \multicolumn{1}{|c|}{ Paraméterek } & $\mathbf{2 0 1 0 / 2 0 4 0 ~ [ \% ] ~}$ & $\mathbf{2 0 4 0 / 2 0 7 0 ~ [ \% ] ~}$ & 2070/2100 [\%] \\
\hline $\begin{array}{l}\text { ETM } \\
\text { (vegyes felszínborítású parcella) }\end{array}$ & $+5(34,53)$ & $+10(35,84)$ & $+11(35,87)$ \\
\hline $\begin{array}{l}\text { ETM } \\
\text { (erdős terület) }\end{array}$ & $+3(37,62)$ & $+9(39,21)$ & $+11(39,40)$ \\
\hline $\begin{array}{l}\text { SOILM } \\
\text { (vegyes felszínborítású parcella) }\end{array}$ & $-5(48,36)$ & $-6(53,35)$ & $-12(60,81)$ \\
\hline $\begin{array}{l}\text { SOILM } \\
\text { (erdős terület) }\end{array}$ & $-5(66,69)$ & $-8(74,30)$ & $-11(82,21)$ \\
\hline $\begin{array}{l}\text { SOILM_MIN } \\
\text { (vegyes felszínborítású parcella) }\end{array}$ & -16 & -20 & -48 \\
\hline $\begin{array}{l}\text { SOILM_MIN } \\
\text { (erdős terület) }\end{array}$ & -11 & -8 & -32 \\
\hline
\end{tabular}
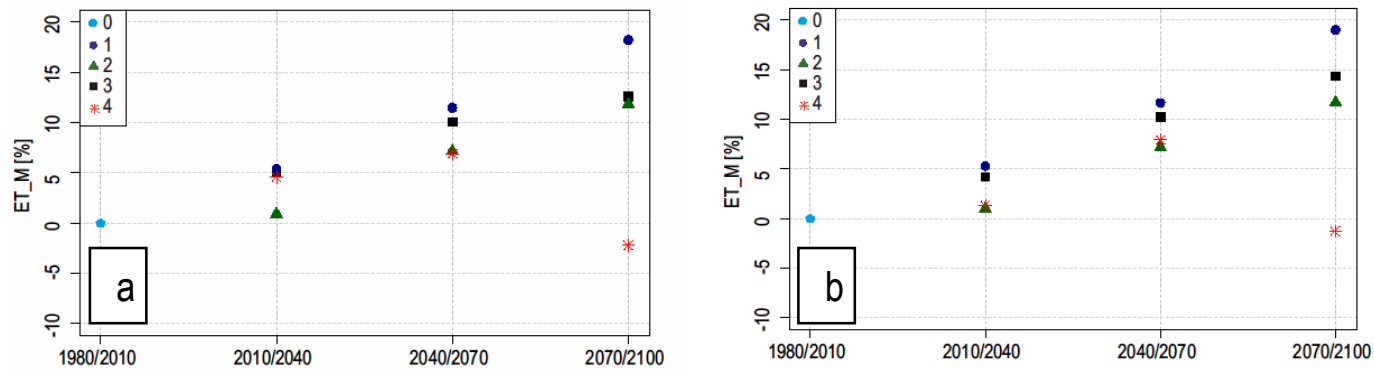

4. ábra: Az elörevetített párolgás átlagértékeinek változása a vegyes felszínboritású parcellán (a) és az erdős területen (b) 1980 és 2100 között.

Figure 4: Projection of the ETM values for mixed parcel (a) and forested area (b) between 1980 and 2100. 

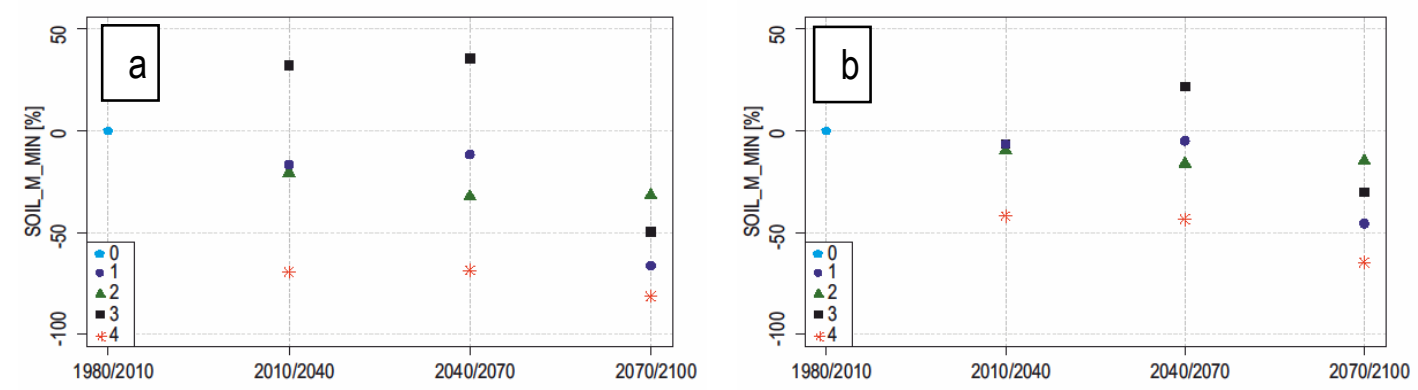

5. ábra: Az elörevetített talajnedvesség minimumok átlagértékeinek változása 1980 és 2100 között a vegyes felszínboritású parcellán (a) és az erdős területen (b.)

Figure 5: Projection of the SOIL M_MIN values for mixed parcel (a) and for forested area (b) between 1980 and 2100.

A 21. század folyamán a REW értékei körülbelül 10\%-ot csökkenek mindkét kutatási terület esetén (88\%-ról, 78\%-ra) (10. egyenlet alapján számítva).

Az SWD esetén a képletből fakadóan (11. képlet) a 40\% feletti értékek jelentik a szárazságstresszt. A szárazságstresszel érintett hónapok aránya, amelyekben tehát a 40\%-ot meghaladja a talajvízdeficit, 2\%-ról (7 hónap a 360 hónapból) 14\%-ra (50 hónap) emelkedik az erdős terület, míg 4\%-ról (14 hónap), 19\%-ra (68 hónap) emelkedik a vegyes felszínborítású parcella területén. Az eredmények alapján elmondható, hogy szignifikáns szárazságstressz a 21. század végére sem várható (5. Táblázat).

5. táblázat: Szárazságstresszes hónapok aránya a talajnedvesség deficit (SWD) érték függvényében.

Table 5: Rates of the months with water stress development during the 21st century in context of the SWD values.

\begin{tabular}{|c|c|c|c|c|}
\hline Kutatási terület & $1980 / 2010$ [\%] & $\mathbf{2 0 1 0 / 2 0 4 0 ~ [ \% ] ~}$ & $\mathbf{2 0 4 0 / 2 0 7 0 ~ [ \% ] ~}$ & $\mathbf{2 0 7 0 / 2 1 0 0 ~ [ \% ] ~}$ \\
\hline Erdős terület & 2 & 9 & 7 & 14 \\
\hline $\begin{array}{c}\text { Vegyes felszínbo- } \\
\text { rítású parcella }\end{array}$ & 4 & 13 & 12 & 19 \\
\hline
\end{tabular}

A bemeneti adatok a vízmérlegmodellhez az Agrárklíma. 2 projektből származnak, amelynél pontosabb adatsor nem állt rendelkezésre.

A kalibrációra használt mért aktuális párolgás (ETCREMAP) (CREMAP adatbázis) validációja eddy-kovarriancia mérésekkel és 5 vízgyuujtő adatainak felhasználásával történt (Szilágyi és mtsai 2011). A mért és a számított értékek erős korrelációt mutatnak $\left(R^{2}=0,8-0,9\right.$ havi szinten, 0,7-0,8 pedig éves szinten). Kisfaludi és mtsai (2015) a CREMAP módszer 9 éves átlagos párolgás értékeit hasonlították össze a MODIS Globális Párolgás Projektjével 
(MOD16). A CREMAP (az RMSE $=17,20 \mathrm{~mm} \cdot$ év$^{-1}$ ) értékével jobb eredményt mutatott, mint a MOD16 (RMSE = 34,12 mm · év-1). Kisfaludi és mtsai (2015) kilenc ismert vízmérleggel rendelkező vízgyüjtő párolgásértékét alkalmazták referenciaként.

A regionális klímamodellek választásából adódó szórás számszerüsitésére több modellt alkalmaztunk (az A1B üvegházgáz kibocsátási forgatókönyv alapján). Szükségességét a klíma-elörejelzés bizonytalansága indokolja, melyet az emissziók jövőbeli alakulása befolyásol (ez a globális technológiai fejlődés teljes hatásától, az energia-felhasználástól, a világ össznépességétől és számos szocio-gazdasági tényezőtőll függ). Fontosak a klímamodellezés korlátai is, amelyek a mindenkori megértésünk függvényében (folyamatok és rendszerek összetettsége, véletlenszerüsége miatt) megköveteli az egyszerüsitéseket a modellezési folyamat során (IPCC 2000; URL2).

A bevezetésben ismertetett tanulmányok, melyek a vízmérlegmodellek hatásvizsgálatával foglalkoztak, alapvetően Thornthwaite típusú havi idölépcsős vízmérlegmodellt mutattak be, de alapvetően éves kiértékeléssel, szemben az általunk jelen tanulmány keretében alkalmazott havi elemzés helyett.

Granier és mtsai (1999) említenek néhány EWM (esetünkben SOILMAX) értéket: $180 \mathrm{~mm}$ (tülevelü állomány, mély talajjal), 72 mm (lombhullató állomány, sekély talajjal) és $185 \mathrm{~mm}$ (lombhullató állomány, mély talajjal). Megállapították, hogy a REW értékei a nedves években nem esnek a 0,4-es határ alá a mély talajok esetén, még az általában legnagyobb stresszel leginkább érintett hónapokban sem (Augusztus és Szeptember). Viszont a 0,4-es határ alá esnek a REW értékei a száraz években, még a mély talajok esetén is. Az általunk vizsgált területeken nagyobb volt a talaj víztározó kapacitása (SOILMAX), ami nagyobb gyökérmélységet is jelent egyúttal (1,8 $\mathrm{m}$ (vegyes felszínborítású parcella); 3,3 $\mathrm{m}$ (erdős terület)). Megjegyzendő, hogy Granier és mtsai (1999) kutatásával ellentétben mi egy talajréteget használtunk, de a szerzők kijelentik, hogy egy rétegként is kezelhető a talaj profil, amennyiben nem áll rendelkezésre elegendő információ. Egyezés, hogy jelen vizsgálat szerint is Augusztusban és Szeptemberben jelentkezett a szárazságstressz mindkét kutatási területen. A vizsgált felszínborítások közül kisebb szárazságstressz várható az erdős terület esetén, mind a kalibrációs mind az előrebecslő szakaszban. A kedvezőbb körülmény oka a mélyebb gyökérzóna, ami jelentősebb víztartalékot biztosít a növények számára, amely hozzávetöleg 1 hónappal hosszabb csapadékmentes időszak átvészelését teszi lehetővé, ha a téli időszakban a talaj nedvességkészletének feltöltése a szántóföldi vízkapacitásig megtörtént.

Remrová és Císleřová (2010) tanulmányában a gyökérmélység (és a talajprofil is) sekélyebb volt, mint a mi esetünkben. Habár csak a vegyes felszínborítású parcellával hasonlítható össze érdemben, hiszen az területét tekintve javarészt szántó. A mi esetünkben 1,8 $\mathrm{m}$, míg az ő esetükben $0,75 \mathrm{~m}$ volt a gyökérmélység. Ez tehát 1,05 méteres különbséget jelent, amelynek oka a nagyobb talajvíz tárkapacitás. Remrová és Císleřová (2010) az elörevetítéseik során jelentéktelen, maximálisan 6 nap/év szárazságstresszes időszakot mutattak ki (2095 nyarán), ami a magasabb éves csapadékösszegnek (1200 mm, ellenben 560 $\mathrm{mm}$ jelen tanulmány esetén) és a hidegebb éves átlaghőmérsékletnek $\left(8,1^{\circ} \mathrm{C}\right.$, a mi ese- 
tünkben tapasztalt $9,7^{\circ} \mathrm{C}$-hoz képest (2070/2100-as vizsgálati periódus)) köszönhető. Tanulmányuk az A2 üvegházgáz kibocsátási forgatókönyvet alkalmazták az elörevetítéseikhez, amely pesszimistább, mint az általunk használt A1B. Továbbá ők egyetlen regionális klímamodellt (HIRHAM/HADCM3) használtak, amíg mi négyet. Ez feltételezhetően hitelesebb eredményt ad figyelembe véve a klímamodell projekciók bizonytalanságait, habár a klímamodellek eredményei korrigálatlanok. Vizsgálati időszakként ők a 2071/2100-as periódust, mi a teljes 21. századot vettük figyelembe. Remrová és Císleřová (2010) az aktuális párolgás éves változását vizsgálták és $12 \%$-os növekedést mutattak ki, míg jelen tanulmányunkban havi átlagok változásait vizsgáltunk (szintén) 30 éves periódusokra és $11 \%$-os aktuális párolgásemelkedést tapasztaltunk a 2070/2100-as periódusban.

Lutz és mtsai (2010) 10\%-os aktuális párolgás-emelkedést mutattak ki az általuk vizsgált 2020/2049-es periódusban a teljes vizsgálati területüket tekintve az 1971/2000-es referencia időszakhoz viszonyítva. Mi az 1980/2010-es referenciaperiódushoz képest 11\%-os emelkedést tapasztaltunk a 2070/2100-as időszakra. Szárazságstresszhez Lutz és mtsai (2010) a PET-AET képletét használták és 23\%-os növekedést tapasztaltak a 2020/2049-es időszakban az 1971/2000 időszakhoz képest, amelynek okaként a jövöben várhatóan emelkedő hőmérsékletet és a csökkenő hóvastagságot jelölték meg. Az általunk alkalmazott REW értékei 88\%-ról (1980/2010) 78\%-ra (2070/2100) csökkentek mindkét kutatási terület esetén. A stresszes hónapok aránya tehát nem esik a 40\%-os kritikus határ alá, hiszen ez a 30 éves perióduson belül (360 hónap) 80 stresszes hónapot jelent mindösszesen a 2070/2100-as időszakban. Az SWD esetén a hónapok aránya, amely a 40\%-ot tehát meghaladja, 2\%-ról (7 hónap/360 hónap) 14\%-ra (50 hónap) emelkedik az erdős terület, míg 4\%-ról (14 hónap), 19\%-ra (68 hónap) emelkedik a vegyes felszínborítású parcella területén. Szignifikáns stressz ezért a 21. század végére sem várható.

Keables és Mehta (2010) kutatásaiban nem foglalkozik elörejelzésekkel a vízmérleg elemeinek tekintetében. A jelenre nézve megállapították, hogy Kansas állam nyugati részén a vízhiány egész évben jelentkezik, amelyet a kevés csapadék és a nyáron megemelkedett aktuális párolgás okoz. Futtatásaink referencia-időszakával összehasonlitva elmondható, hogy az 1980/2010-es periódusban mindössze 2\% (erdős terület) és 4\% (vegyes felszínborítású parcella) a stresszes hónapok aránya.

A bemutatott vízmérlegmodell hatás tanulmányok (Granier és mtsai 1999; Remrová és Císleřová, 2010; Lutz és mtsai 2010; Keables és Mehta 2010) egyaránt emelkedő aktuális párolgás adatokat jeleznek elöre, ugyanakkor csökkenő talajnedvesség tartalmat, melynek okaként a jövőre prognosztizált csökkenő csapadékot és a feltételezhetően emelkedő hőmérsékletet jelölik meg. Következésképpen a vízhiánnyal fokozottan számolni kell a 21. század folyamán, habár a konkrét tendenciák régiónként különbözőek. 


\section{ÖSSZEFOGLALÁS}

A jelen cikkhez kapcsolódó kutatás keretében egy egyszerüsített Thornthwaite alapú, havi idölépcsős vízmérleg modellt fejlesztettünk ki. A modellt sikeresen kalibráltuk két különböző felszínborításra (egy vegyes felszínborítású parcellára, Mosonmagyaróvár mellett és egy erdős területre Sopron mellett). A kalibrációhoz távérzékelt aktuálispárolgás-térképeket használtunk.

A modell előnye annak robosztus felépítése, mivel a kalibrált modell csak hőmérséklet és csapadék adatokat igényel a futtatáshoz. A kalibrációs paraméter felszínfüggő potenciális párolgás és a talaj víztároló kapacitása (SOILMAX).

Elsődlegesen vízgyüjtő szinten és olyan területeken használható a modell, ahol nincs pótlólagos víz utánpótlás a felszínről, vagy felszín alól.

A kalibrált modellekkel a regionális klímamodellek hőmérséklet és csapadék adatainak felhasználásával elörevetítéseket végeztünk a vízforgalomra és a vízmérleg egyes elemeire (párolgás és talajnedvesség). Mindegyik futtatás enyhén emelkedő párolgást (mindkét kutatási terület esetén $+11 \%$ ), de erősen csökkenő talajnedvesség minimum értékeket valószínüsít (vegyes felszínborítású parcella: $-48 \%$; erdős terült: $-32 \%$ ) a 21. század végére. Következésképpen a jövőben a párolgási kényszer növekedésének hatására a párolgás növekedni fog, és az elpárolgó vízmennyiség, mivel a nyári időszakban a csapadékból alig tud majd utánpótolódni, ezért drasztikusan csökkenti majd a talajban raktározott vízkészleteket. A csökkenő talajnedvesség minimumok a szárazságstresszes időszakok egyre súlyosabb megjelenését vetítik előre, az erre érzékeny fafajok potenciális veszélyeztetésével.

Az erdős területen kisebb szárazságstressz várható mind a kalibrációs időszak, mind az előrejelzés időszakában. Habár az erdő párolgása nagyobb, de a kedvezőbb körülményeket - a mélyebb gyökérzóna révén-a jelentősebb mennyiségü (hasznosítható) hozzáférhető vízkészlet biztosítja, így hosszabb csapadékmentes időszak átvészelésére képes. Azonban, ha aszályos időszak hossza már meghaladja a 2 hónapot a vizsgált erdősült terület is szárazságstresszes állapotba kerülhet.

\section{KÖSZÖNETNYILVÁNITÁS}

A kutatás az Agrárklíma.2 (VKSZ_12-1-2013-0034) EU-nemzeti kutatási és fejlesztési projekt támogatásával valósult meg. Kalicz Péter munkarésze a Bolyai János Kutatási Ösztöndíj támogatásával készült. Gribovszki Zoltán munkája a kutatásban az Európai Unió és Magyarország támogatásával, az Európai Szociális Alap társfinanszírozásával a TÁMOP 4.2.4.A/2-11-1-2012-0001 azonosító számú „Nemzeti Kiválóság Program - Hazai hallgatói, illetve kutatói személyi támogatást biztositó rendszer kidolgozása és működtetése konvergencia program" címü kiemelt projekt keretei között valósult meg. 


\section{FELHASZNÁLT IRODALOM}

Bartholy J., Bozó L. \& Haszpra L. 2011: Klímaváltozás - 2011, Klímaszcenáriók a Kárpát-medence térségére. Magyar Tudományos Akadémia, Eötvös Loránd Tudományegyetem, Meteorológiai Tanszék.

Christensen J.H. \& Van Meijgaard E. 1992: On the construction of a regional atmospheric climate model. Technical Reports - Royal Netherlands Meteorological Institute, (TR-147).

Christensen J.H., Bøssing Christensen O., Lopez P., van Meijgaard E., \& Botzet M. 1996: The HIRHAM4 Regional Atmospheric Climate Model. Scientific Report 96-4, Danish Meteorological Institute.

Christensen J.H. \& Christensen O.B. 2007: A summary of the PRUDENCE model projections of changes in European climate by the end of this century. Climatic Change 81: 7-30. DOI 10.1007/s10584-006-9210-7

Dövényi Z. 2010: Magyarország kistájainak katasztere - második, átdolgozott és bővített kiadás. MTA, Budapest.

Dingman L.S. 2002: Physical hydrology. Upper Saddle River, N.J., Prentice Hall.

Gálos B., Führer E., Czimber K., Gulyás K., Bidló A., Hänsler A., Jacob D. \& Mátyás Cs. 2015: Climatic threats determining future adaptive forest management - a case study of Zala County. Időjárás 119(4): 425-441.

Granier A., Breda N., Biron P. \& Villette S. 1999: A lumped water balance model to evaluate duration and intensity of drought constraints in forest stands. Ecological Modelling 116: 269-283. DOI: 10.1016/s0304-3800(98)00205-1

Guitjens J.C. 1982: Models of alfalfa yield and evapotranspiration. Journal of the Irrigation and Drainage Division 108(3): 212-222.

Hamon W.R. 1963: Computation of direct runoff amounts from storm rainfall. International Association of Scientific Hydrology Publication 63: 52-62.

HREX jelentés. Lakatos M., Szépszó G., Bihari Z., Krüzselyi I., Szabó P., Bartholy J. et al. 2012: Éghajlati szélsőségek változásai Magyarországon: Közelmúlt és jövő - A magyarországi eredmények összefoglalása az IPCC szélsőséges éghajlati események kockázatáról és kezeléséről szóló Tematikus Jelentéshez kapcsolódóan. Országos Meteorológiai Szolgálat, Budapest.

IPCC 2000: Emissions scenarios. In: Nakicenovic N. \& Swart R. (eds) Contribution of Working Group III to the Special Report of the Intergovernmental Panel on Climate Change. Cambridge University Press, Cambridge, United Kingdom.

IPCC 2014: Summary for Policymakers. In: Climate Change 2014, Mitigation of Climate Change. Contribution of Working Group III to the Fifth Assessment Report of the Intergovernmental Panel on Climate Change. Cambridge University Press, Cambridge, United Kingdom and New York, USA.

Jacob D. 2001: A note to the simulation of the annual and inter-annual variability of the water budget over the Baltic Sea drainage basin. Meteorology and Atmospheric Physics 77: 61-73. DOI: 10.1007/s007030170017

Jacob D., Barring L., Christensen O.B., Christensen J.H., Castro M., DeUe M., et al. 2007: An inter-comparison of regional climate models for Europe: model performance in present-day climate. Climatic Change 81:3152. DOI: $10.1007 / s 10584-006-9213-4$

Jacob D., Kotova L., Lorenz P., Moseley C.H. \& Pfeifer S. 2008: Regional climate modeling activities in relation to the CLAVIER project. Időjárás 112: 141-153.

Jones C.G., Ullerstig A., Willen U. \& Hansson U. 2004: The Rossby Centre regional atmospheric climate model (RCA). Part I: model climatology and performance characteristics for present climate over Europe. AMBIO: A Journal of the Human Environment 33(4): 199-210. DOI: 10.1579/0044-7447-33.4.199

Keables M.J. \& Mehta S. 2010: A soil water climatology for Kansas. Great Plains Research: A Journal of Natural and Social Sciences 20: 229-248. 
Kisfaludi B., Csáki P., Primusz P., Péterfalvi J. \& Gribovszki Z. 2015: Comparison of CREMAP and MODIS MOD16 evapotranspiration. International conference: Catchment processes in regional hydrology, Linking experiments and modelling in Carpathian drainage basins 2015.10.29. Vienna.

Kisházi P. \& Ivancsics J. 1985: Sopron Környéki Üledékek Összefoglaló Földtani Értékelése. Kézirat, Sopron.

Kovács Á. 2011: Tó- és területi párolgás becslésének pontosítása és magyarországi alkalmazásai. PhD értekezés, Budapesti Müszaki és Gazdaságtudományi Egyetem, Építőmérnöki Kar, Budapest.

Linden van der P., Mitchell J.F.B. (eds) 2009: ENSEMBLES: Climate Change and its Impacts: Summary of research and results from the ENSEMBLES project. Met Office Hadley Centre, FitzRoy Road, Exeter EX1 3PB, UK.

Lutz J.A., Wagtendonik J.W. \& Franklin J.F. 2010: Climatic water deficit, tree species ranges, and climate change in Yosemite National Park. Journal of Biogeography 37: 936-950. DOI: 10.1111/j.13652699.2009.02268.x

Marosi S. \& Somogyi S. (eds) 1990: Magyarország Kistájainak Katasztere I. MTA Földrajztudományi Kutató Intézet, Budapest.

Mika J., 1999: Klímaforgatókönyvek a nemzeti stratégia fejlesztéséhez a vízgazdálkodásiban. In: Somlyódy L. (eds): Nemzeti vízgazdálkodás stratégia. Magyar Tudományos Akadémia, Budapest.

Mingteh Cs. 2006: Forest Hydrology: An introduction to water and forests (second edition). Stephen F. Austin State University, Texas, U.S.A.

Morton F.I., Ricard F. \& Fogarasi S. 1985: Operational estimates of areal evapotranspiration and lake evaporation: Program WREVAP. National Hydrological Research Institute, Ottawa: Inland Waters Directorate.

Muggeo V.M.R. 2008: Segmented: an R package to fit regression models with broken-line relationships. R News 8(1): 20-25.

Neilson R. 1995: A model for projecting continental-scale vegetation distribution and water balance. Ecological Applications 5(2): 362-385. DOI: 10.2307/1942028

Nováky B. \& Bálint G. 2013: Shifts and Modification of the Hydrological Regime Under Climate Change in Hungary. In: Singh B.R. ed. Climate Change - Realities, Impacts Over Ice Cap, Sea Level and Risks, Chapter 6. DOI: $10.5772 / 54768$

Pongrácz R., Bartholy J. \& Miklós E. 2011: Analysis of projected climate change for Hungary using ENSEMBLES simulations. Applied Ecology and Environmental Research 9(4): 387-398. DOI: 10.15666/aeer/0904_387398

Priestley C.H.B. \& Taylor R.J. 1972: On the assessment of surface heat flux and evaporation using large-scale parameters. Monthly Weather Review 100(2): 81-92. DOI: 10.1175/1520-0493(1972)100 $<0081$ :otaosh $>2.3 . c 0 ; 2$

R Core Team 2012: R: A language and environment for statistical computing. R Foundation for Statistical Computing, Vienna, Austria.

Remrová M. \& Cislerová M. 2010: Analysis of climate change effects on evapotranspiration in the watershed Uhlírská in the Jizera mountains. Soil and Water Research 5(1): 28-38. DOI: 10.17221/5/2009-swr

Sun G.K., Alstad J., Chen S., Chen C.R., Ford G., Lin C. et al. 2011: A general projective model for estimating monthly ecosystem evapotranspiration. Ecohydrology 4(2): 245-255. DOI: 10.1002/eco.194

Szilágyi J. \& Józsa J. 2008: Klímaváltozás és a víz körforgása. Magyar tudomány 169(6): 698-703.

Szilágyi J. \& Józsa J. 2009: Estimating spatially distributed monthly evapotranspiration rates by linear transformations of MODIS daytime land surface temperature data. Hydrology and Earth System Sciences Discussions 13(5): 629-637. DOI: 10.5194/hessd-6-1433-2009

Szilágyi J. \& Kovács Á. 2010: Complementary-relationship-based evapotranspiration mapping (CREMAP) technique for Hungary. Periodica Polytechnica Civil Engineering 54(2): 95-100. DOI: 10.3311/pp.ci.20102.04 
Szilágyi J. Kovacs A. \& Józsa J. 2011: A calibration-free evapotranspiration mapping (CREMAP) technique. In: Łabędzki L. (ed) Evaporation, Chapter 11. DOI: 10.5772/14277

Thornthwaite C.W. \& Mather J.R. 1955: The water balance. Drexel Institute of Technology, Laboratory of Technology, Publications in climatology. Philadelphia.

Vörösmarty C.J., Federer C.A. \& Schloss A.L. 1998: Potential evaporation functions compared on US watersheds: Possible implications for global-scale water balance and terrestrial ecosystem modeling. Journal of Hydrology 207: 147-169. DOI: 10.1016/s0022-1694(98)00109-7

Wilson B.N. \& Brown J.W. 1992: Development and evaluation of a dimensionless unit hydrograph. Journal of the American Water Resources Association 28: 397-408. DOI: 10.2166/nh.1972.0007

\section{On-line források}

URL1: Klímabarát Települések Szövetsége. http://klimabarat.hu/node/96 (Letöltés dátuma: 2014.01.31.)

URL2: Infrastructure for the European Network for Earth System Modelling / Background \& topics / Climate model data / Uncertainties. https://climate4impact.eu/impactportal/documentation/backgroundandtopics.jsp?q=Uncertainties (Letöltés dátuma: 2017.08.10.)

Érkezett: 2018. május 2.

Közlésre elfogadva: 2018. május 29. 